\title{
Coupling a collaborative digital map and a dashboard: an optimal starting point for urban project learning in engineer training? The case of the serious game "Urb'Act"
}

\author{
Nathalie MOLINES*, Carine HENRIOT \\ ${ }^{a}$ Sorbonne University, Université de Technologie de Compiègne - AVENUES EA 72841, nathalie.Molines@utc.fr, \\ carine.henriot@utc.fr \\ * Corresponding author
}

Keywords: Urban project, serious game, Tatin Table, collaborative planning, innovative pedagogy

\begin{abstract}
:
As highlighted by Bacquet and Gauthier (2011), the shift from government of cities to urban governance "results in much greater variety of project scales, stakeholders and forms of public-private partnership. For the last two decades, it has contributed to fundamentally transforming the work of urban planners." The foundations of this multi-stakeholder construction of urban projects must be addressed in the training of future city planners. But this training is difficult as part of a traditional education as it has to lead students to become aware of the multitude of direct, indirect and induced effects of involving multiple stakeholders with sometimes contradictory needs.
\end{abstract}

Games, be they or not serious, digital or cooperative, have often been used in urban planning projects (Poplin, 2011) and their learning benefits are widely recognized (Cohard P. 2015; GEE JP 2003). Fun, more or less complex learning materials have been developed to address the complexity of the decision-making process in urban planning (Cools 2014; Vilmin 2018; etc.)

As part of the "Urb'Act" project, selected in Sorbonne Université's FORMINNOV call for projects, we have sought to draw on the potential offered by digital tools and touchscreen technologies to develop innovative teaching materials. To begin with, the game seeks to raise generalist urban engineers' awareness of the complexity of urban projects.

Urb'Act thus aims to help non-specialists to understand the interactions between the various stakeholders of an urban project. As a key aspect of an inverted pedagogy, Urb'Act also introduces notions of the construction of an overall plan, balancing of a budget and the sustainability of projects (Molines N. et al., 2018).

The game equipment is a digital platform combining a large touch-screen table representing the study territory and a vertical screen serving as a dashboard, calculating a set of indicators as the players act on the territory (cf Figure 1).

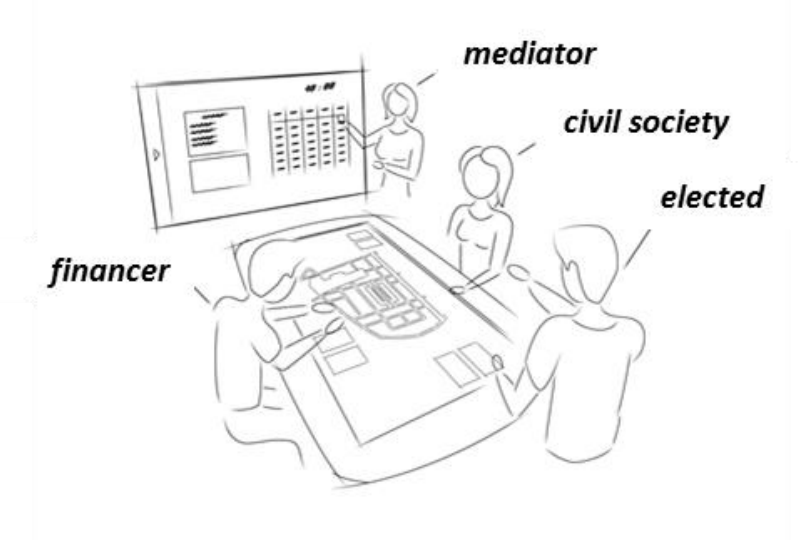

Figure 1. the Urb'Act platform.

By acting on the map (ground plane), players thus cause the indicators to change - positively or negatively. After a short period of work to familiarize players with the equipment and the creation of a ground plane, roles (project owner, 
civil society, investors) are allocated and overall or personal objectives are defined. Outside events also bring disruption to gameplay (cf figure 2).

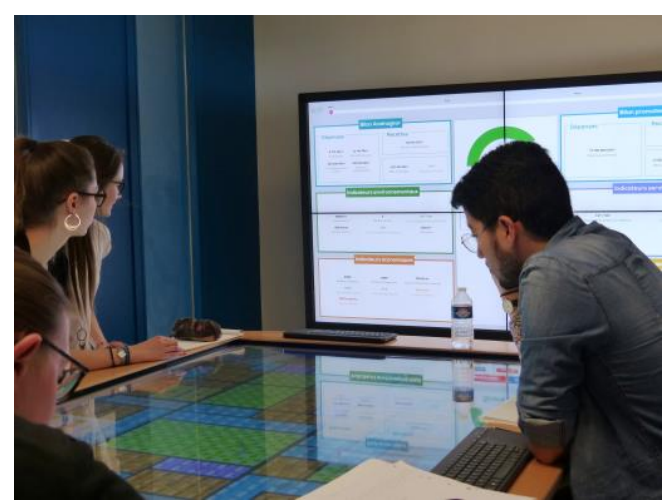

Figure 2 : game in progress !

This contribution will be an opportunity to present the game and discuss the benefits and limitations of a digital and collaborative serious game in the training of engineering students. We will also take time to look at the potential of coupling a collaborative digital map and a dashboard for players' learning.

Bacqué, M.H.; Gauthier, M., (2011). Participation, urbanisme et études urbaines. Quatre décennies de débats et d'expériences depuis "A ladder of citizen participation » de S. R. Arnstein (Participation, Urbanism, and Urban Studies: Four Decades of Debates and Experience since "A Ladder of Citizen Participation" by S. R. Arnstein), Participations, 2011/1 (No. 1), pp. 36-66. DOI: 10.3917/parti.001.0036. URL : https://www.cairn.info/revueparticipations-2011-1-page-36.htm.

Cohard, P., (2015). L'apprentissage dans les serious games : proposition d'une typologie (Learning in serious games: proposal for a typology). @GRH, 16,(3), 11-40. doi:10.3917/grh.153.0011. http://www.cairn.info/revue-@grh-2015-3-page11.htm.

Cools, M., (2014). Le «serious game » peut-il être un outil utile au développement du territoire? (The "serious game": can it be a useful tool for urban planning?). Paper presented at Le serious game : un outil pour la planification urbaine? (The serious game: a tool for urban planning?), Liège, Belgium.

http://hdl.handle.net/2268/170845

Gee, J.P., (2003). What Video Games Have to Teach Us About Learning and Literacy Computers in Entertainment (CIE), Theoretical and Practical Computer Applications in Entertainment archive, vol. 1, Issue 1, October 2003. DOI:10.1145/950566.950595.

https://historysfuture.files.wordpress.com/2013/09/gee-what-video-games-3pp.pdf

Molines N, Henriot C., Gidel T., Fanni M., Korbi F., (2018). URB'ACT, Un serious game numérique pour l'apprentissage de la co production du projet urbain. Ou le délicat équilibre entre simplification de la réalité et contraintes techniques, In Deboudt P., Bosredon P., Castex E., Dumont F., Dumont M., Groux A., Menerault P., Paris P., Prévot M., Scarwell H.-J. (dir.), 2018, Actes du colloque des 20èmes rencontres internationales en urbanisme de l'APERAU "Que reste-t-il du projet ?", Université de Lille, IAUL, Laboratoire TVES, Lille, p. $290-297$. https://hal.archives-ouvertes.fr/hal-01870239/document

Poplin, A., (2011). Games and Serious Games in Urban Planning: Study Cases. In: Murgante B., Gervasi O., Iglesias A., Taniar D., Apduhan B.O. (eds.) Computational Science and Its Applications - ICCSA 2011. ICCSA 2011. Lecture Notes in Computer Science, vol. 6783. Springer, Berlin, Heidelberg.

Vilmin, T., 2018. Urbax, une simulation jouée de l'aménagement urbain (Urbax, an urban development serious game), journée d'études sur le jeu sérieux urbains (study day on urban serious games), Compiègne (France), 27 November 2018. 